\title{
Circumstantial evidences for mimicry of scorpions by the neotropical gecko Coleodactylus brachystoma (Squamata, Gekkonidae) in the Cerrados of central Brazil
}

\author{
Reuber Albuquerque Brandão ${ }^{1}$ and Paulo Cesar Motta ${ }^{2}$ \\ 1 Diretoria de Ecossistemas, Instituto Brasileiro do Meio Ambiente - IBAMA. SCEN Trecho 2, 70 818-900, Brasília, \\ DF, Brazil. E-mail: reuberbrandao@yahoo.com.br. \\ 2 Departamento de Zoologia, Universidade de Brasília - UnB, 70 910-900, Brasília, DF, Brazil. E-mail: \\ aracnideos@unb.br.
}

\begin{abstract}
Circumstantial evidences for mimicry of scorpions by the neotropical gecko Coleodactylus brachystoma (Squamata, Gekkonidae) in the Cerrados of central Brazil. There are few records of invertebrates mimicry by reptiles. In the Cerrados of central Brazil, the small Coleodactylus brachystoma is an endemic species common in the islands and margins of the Serra da Mesa hydroelectric dam reservoir. When cornered, this lizard folds the tail over the body exposing the pale-orange ventral surface. Lizard behavior, tail length and color pattern confer to this lizard a strong resemblance with syntopic buthid scorpions Rhopalurus agamenon, Tytius matogrossensis, and Anantheris balzani. Lizards and scorpions share the same tail color, size, and shape. Ecologically, they use the same microhabitats, are exposed to the same potential predators, and present similar behaviors when threatened.
\end{abstract}

Keywords: Squamata, Gekkonidae, Coleodactylus brachystoma, mimicry, Rhopalurus agamenon, Tytius matogrossensis, Anatheris balzani, buthid scorpions, Cerrado, central Brazil.

\section{Introduction}

Mimicry is an ecological relationship of central importance in the evolutionary biology, since it deals directly with the occurence of natural selection, i.e., the differential survivor of individuals by having easyly identifible characteristics and/or behaviors.

Received 4 January 2005.

Accepted 9 November 2005.

Distributed December 2005.
At least three organisms are envolved in mimetic systems - a toxic or dangerous model, a harmless mimic and a "duped" predator. Experienced predators avoid the model as so the mimics that shares with the model some characteristics or behaviors. The occurrence of mimicry in the nature was firstly suggested by H. W. Bates (1862), who noted that predatory birds avoided palatable butterflies with the same color pattern of toxic ones. As the harmless butterflies were less abundant that the models, Bates suggested that predators find the models 
more times than mimics, leading to learning for avoidance the model's color pattern. This kind of mimicry is called Batesian Mimicry.

In some cases, the model involved in mimicry systems is so dangerous that learning is unlike. In these cases, several predators show innate avoidance of the model's patterns, and some mimics could be less precise copies of the models (Pough 1988a, b).

Although there are several examples of mimicry among invertebrates and some invertebrates that mimic vertebrates, the examples of mimicry of invertebrates by vertebrates are very scarce. Specifically in lizards, there are only three well documented examples (Huey and Pianka 1977, Autumn and Han 1989, Vitt 1992). However, the studies on vertebrate mimicry are based mostly on naturalistic observations, lacking experimental tests.

Some lizards mimic noxious, toxic, or potentially dangerous invertebrates such as millipedes, beetles, and scorpions (Huey and Pianka 1977, Autumn and Han 1989, Vitt 1992, Pianka and Vitt 2003). Lizards can resemble invertebrate models in color and/or behavior. Juveniles of the lizard Eremias lugubris resemble the noxious carabid beetle Anthia sp. in color pattern and walking behavior (Huey and Pianka 1977). When moving, juveniles of the nocturnal Chinese gekkonid Teratoscincus roborowskii fold the tail over the body, resembling the large sympatric buthid scorpion Mesobuthus sp., which is very common in the area (Autumn and Han 1989). The color pattern of young Diploglossus lessonae, a South American anguid lizard, resembles the noxious millipede Rhinocricus albidolimbatus. Indeed, lizards give birth in the maximum seasonal abundance of the millipede (Vitt 1992).

Pianka and Vitt (2003) stressed that several Australian gekkonid lizards fold their tails over the body when active, providing the lizard some resemblance with scorpions. This behavior also exposes the lizard's tail to predators, directing attacks to this part of the body. This behavior seems very common and widespread in gekkonid lizards (e.g., Colli et. al. 2003, Pinka and Vitt 2003).

Although invertebrate mimicry by vertebrates could be more common than previously imagined (Vitt 1992), observations on reptiles that mimic invertebrates are scarce. Here we report the presumed mimicry of scorpions by the small Neotropical sphaerodactyline Coleodactylus brachystoma, an endemic lizard species from the Cerrados of central Brazil.

\section{Material and Methods}

Observations were made in margins and islands formed during the flooding of the Serra da Mesa hydroelectric dam, Minaçu, Goiás state, Brazil (48 $\left.20^{\prime} \mathrm{W}, 13^{\circ} 51^{\prime} \mathrm{S}\right)$. Islands ranged from 0.5 to 15 ha (Table 1 ) and were covered by open Cerrado vegetation (sensu Eiten 1994; Ribeiro and Walter 1998). Vegetation structure and number of retreat sites were similar among islands (Brandão 2002).

Lizards and scorpions were sampled using a total sample method (see details in Brandão 2002), where all animals in a $50 \times 50 \mathrm{~m}$ fenced square were captured. Five squares were located in the islands and five in the lake margins. During the sampling, all retreat sites used by lizards and scorpions - as termite mounds, rock crevices, soil holes, dead logs, tree trunks, and soil debris - were carefully checked and counted. About three days were spent in each square and four people were envolved in sampling. All lizards were measured, following Ricklefs et al. (1981), using digital calipers (0.01 mm). Tail length was measured only from lizards with undamaged tails. The length of lizards tails and scorpion metasomas were compared by ANOVA, and pair to pair comparisons were tested by Kruskall-Wallis analysis of variance. The significance level was set to 0.05 .

Lizards defensive responses of 16 individuals were induced in the lab by touching lizard heads with small wood sticks or forceps. In the field, behaviors were commonly started by disturbance due to debris removal. 
Table 1 - Comparisons of lizard and scorpion abundance in the sampled quadrats. The total area size refers to the area of Cerrado remnant in the island and margins of the Serra da Mesa lake. The name of sampled sites follows the original area names.

\begin{tabular}{|c|c|c|c|c|c|c|c|c|c|c|c|}
\hline SAMPLED SITES & $\mathrm{I} 42$ & I 41 & I 42.2 & Edge 1 & Edge 2 & $\mathrm{I} 34$ & $\mathrm{I} 38$ & $\mathrm{I} 37$ & I 35 & I 1 & TOTAL \\
\hline Situation & edge & edge & edge & edge & edge & island & island & island & island & island & \\
\hline Total area size (ha) & $>1,000$ & $>1,000$ & $>1,000$ & $>1,000$ & $>1,000$ & 6 & 3 & 2 & 15 & 0.5 & \\
\hline SPECIES & & & & & & & & & & & \\
\hline Coleodactylus brachystoma & 8 & 1 & 18 & 3 & 1 & 2 & 21 & 26 & 15 & 66 & 165 \\
\hline Rhopalurus agamenon & 5 & 3 & 6 & 10 & 3 & & 10 & 5 & 9 & 5 & 56 \\
\hline Tytius matogrossensis & 3 & 1 & & & & & & & & 1 & 5 \\
\hline Anantheris balzani & 9 & & & & & & & & & & 9 \\
\hline Total lizard abundance & 8 & 1 & 18 & 3 & 1 & 2 & 21 & 26 & 15 & 66 & 165 \\
\hline Total scorpion abundance & 17 & 4 & 6 & 10 & 3 & 0 & 10 & 5 & 9 & 6 & 70 \\
\hline
\end{tabular}

\section{Results}

A total of 165 lizards and 70 scorpions (56 Rhopalurus agamenon, nine Anantheris balzani, and five Tytius matogrossensis) were found in the 10 sampled squares (Table 1 ). The lizard abundance by square varied from 1 to 66 (mean \pm SD: $16.1 \pm 19.75$ ), whereas the total scorpion abundance varied from 0 to17 ( \pm \pm 7.74$)$. However, there was no difference in scorpion and lizard abundances in the sampled squares $\left(\mathrm{U}_{(1,10)}=0.52 ; p=0.47\right)$.

All lizards tested in lab showed the defensive behavior that consisted of folding the tail over the body, exposing the ventral aspect (Figure 1). The dorsal coloration of the trunk and tail of Coleodactylus brachystoma is dark brown to gray, and camouflage the lizard against the substrate. The ventral coloration of the tail is yellowish to pale-orange.

The coloration of lizard tail matches the metasoma of Tityus matogrossensis, Anantheris balzani, and Rhopalurus agamenon, the buthids scorpions sympatric with Coleodactylus brachystoma. Scorpions in the family Buthidae are some of the most poisonous of South America, and at least $T$. matogrossensis has been responsible for mid-serious human attacks (Lourenço and von Eickstedt 2003). In Serra da Mesa, C. brachystoma uses the same microhabitats as $R$. agamenon, A. balzani, and T. matogrossensis. In addition, the length of lizard tails falls within the range of the scorpion metasoma length (Figure 2 ), and there is no significant difference in tail length of Coleodactylus and scorpions $(f=$ 87.99; $\mathrm{p}<0.001)$ and in tail length of the lizard and metasoma length of $T$. matogrossensis $\left(\mathrm{U}_{(1}\right.$, 28) $=35.00 ; \mathrm{p}=0.083$ ).

When located, most lizards tried to escape into small holes, crevices or under soil debris. When cornered or touched, they immediately folded the tail, forming an arc, resembling to the way scorpions expose the metasoma in defensive situations. In lab tests, lizards promptly assumed the defensive posture, folding the tail over the body and exposing the colored ventral surface of the tail. If the stimulus is maintained, the lizard also moves the tail sideways.

The dorsal color of the prosoma and mesosoma of T. matogrossensis, A. balzani and $R$. agamenon enable these scorpions to camouflage against the substrate. The metasoma, however, is very distinctive from the other body segments, mostly because of its characteristic morphology and pale-yellow to orange coloration.

\section{Discussion}

The tails of sphaerodactyline lizards genera Coleodactylus, Pseudogonatodes, Gonatodes, and Gymnodactylus are well known by its easy autotomy (Ávila-Pires 1995, R. A. Brandão, 

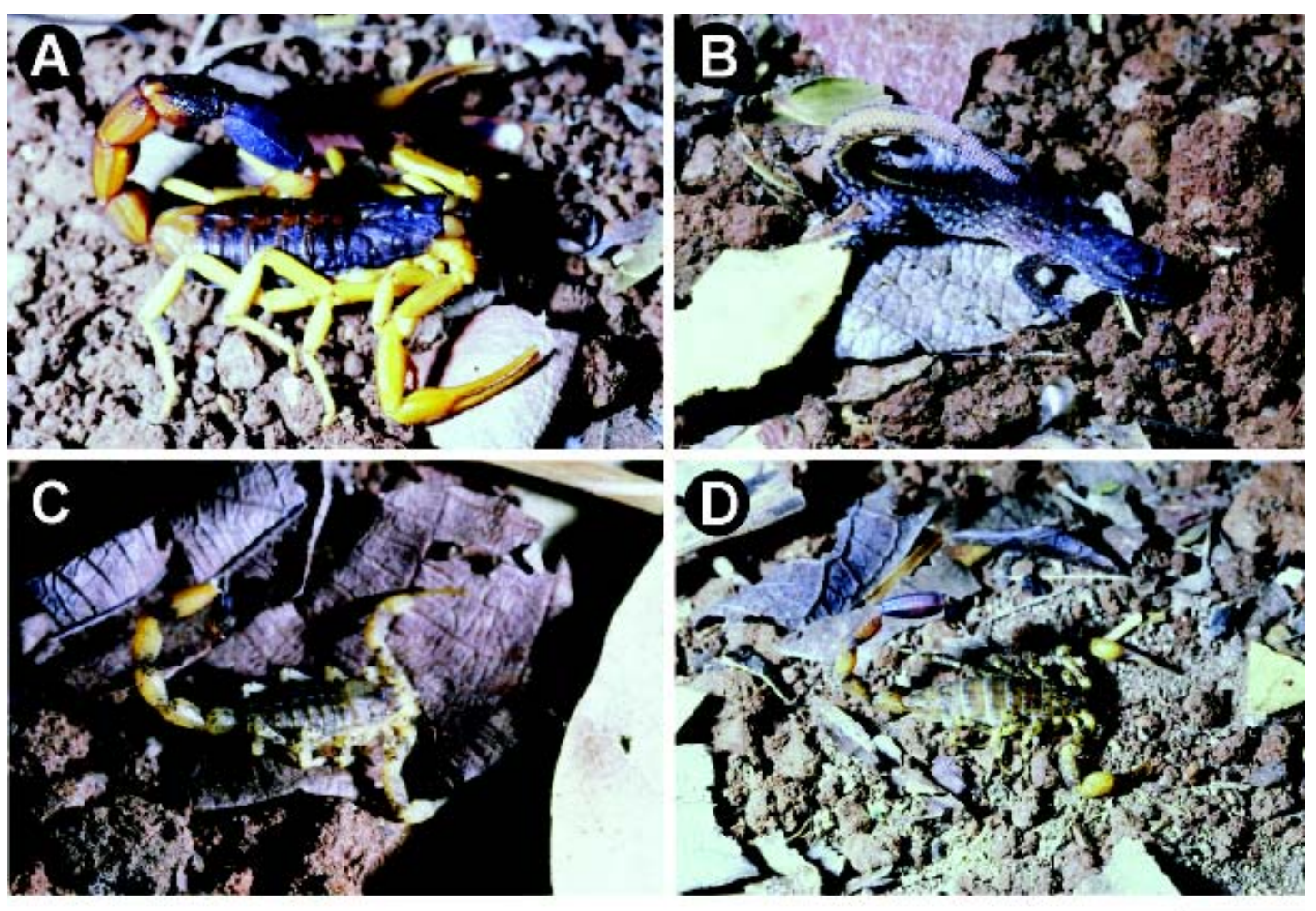

$10 \mathrm{~mm}$

Figure 1 - Defensive posture of scorpions and the lizard Coleodactylus brachystoma. (A) Rhopalurus agamenon; (B) C. brachystoma, showing the orange-pale coloration of the ventral surface of the tail and the resemblance with scorpion species; (C) Tytius matogrossensis; (D) Anantheris balzani. Animals are arranged by size. Bar corresponds to $10 \mathrm{~mm}$. Photographs by RAB.

pers. obs.). Tail autotomy is an efficient lizard defense, presumably more advantageous for small bodied species (Vitt and Copper 1986, Pianka and Vitt 2003). Several Neotropical lizards in the families Gekkonidae, Scincidae, and Gymnophtalmidae have long, colored and autotomic tails, and present strategies to attract the predators attack (Vitt and Copper 1986, Brandão 2002). By folding the tail over the body, Coleodactylus brachystoma expose the tail to predators. The ventral color pattern of the tail and lizard behavior stresses the resemblance with scorpions (Autumn and Han 1989). Coleodactylus brachystoma is the only species in the genus that have different ventral and dorsal tail colors (Ávila-Pires 1995, T. C. ÁvilaPires pers. com., G. R. Colli pers. com.). Mimicry and tail exposition to predators are not mutually exclusive explanations, and could have a cumulative effect, enhancing the protection against predators of this lizard.

In Serra da Mesa, some visually oriented predators such as the rusty-margined guan (Penelope superciliaris), the smooth-billed ani (Crotophaga ani), the guira cuckoo (Guira guira), fly-catchers (Pitangus sulphuratus, Myiarchus spp., Tyrannus melancholicus), the red-legged seriema (Cariama cristata), and 


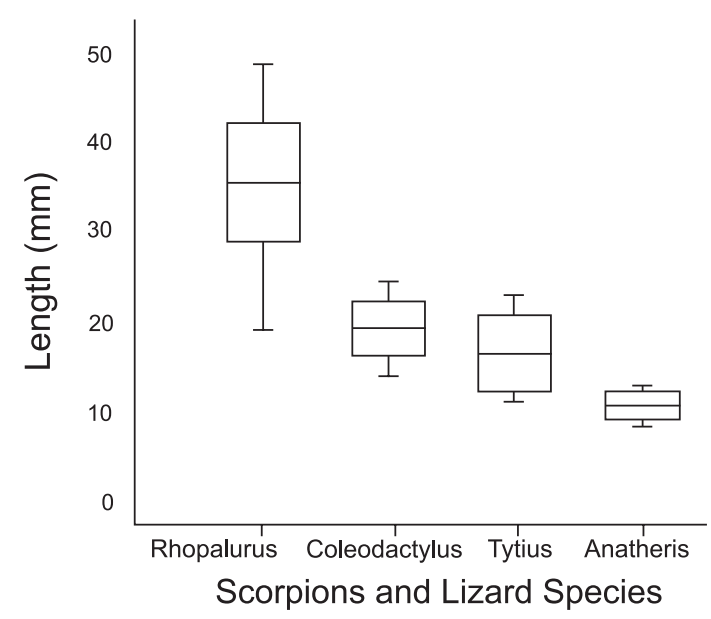

Figure 2 - Mean (transversal bar in the middle of the box), Standard Deviations (box) and Range (transversal bars) of the length values (in $\mathrm{mm}$ ) for the metasoma of the scorpions (Rhopalurus agamenon (Mean \pm SD, Range): $35.80 \pm$ 6.60, 19.75 - 48.74; Tytius matogrossensis: $16.93 \pm 4.06,11.56-23.21$; Anantheris balzani: $11.22 \pm 1.47,9.02-$ 13.28), and tail of Coleodactylus brachystoma $(19.76 \pm 2.98 ; 14.42-24.88)$.

larger lizards (Mabuya nigropunctata, Ameiva ameiva, Cnemidophorus ocellifer, Tupinambis spp.), usually scratch and remove soil debris when searching for food (pers. obs.). Under this kind of disturbance, Coleodactylus brachystoma could assume the defensive posture. On several occasions, the people involved in sampling were lured by lizard defense responses when removing soil debris, and believed lizards were scorpions. However, we lack information if the cited potential predators feed upon buthid scorpions, or if some of they shows innate avoidance of scorpions.

Scorpions have several characteristics important for the evolution of mimicry (as a model), such as antiquity (scorpions are among the most ancient terrestrial invertebrates) and distinctive and evident weaponry, allied to characteristic and easily identifiable morphology. Primitive scorpions had stings and probably were dangerous to predators. Scorpion poison causes intense pain and, in some cases, can kill non-specialist predators (Brownell and Polis 2001). Fatal models promote the evolution of abstract mimetic systems, where mimics shows some general characteristics shared by a group of dangerous species, and are not the perfect copy of a unique noxious species (Pough 1988a, b). The abstract mimicry enables imperfect mimics to be avoided by predators. As pointed by Wüster et al. (2004), a venon apparatus capable of causing severe loss of fitness to any non-specialist predator can provide relative security from predation not only to the venomous prey, but also to other animals sufficiently similar to be mistaken for a dangerous one.

Although most scorpions have discrete colorations (Heatwole 1967), they show aposematic behavior by displaying the tail. The metasoma length of scorpions matches the tail of several lizard species (young and adults). The scorpion tail is the most distinctive part of the animal and is essential for its identification by predators (Heatwole 1967). Ecologically, the activity time of scorpions and gekkonid lizards is similar. Furthermore, scorpions and Coleodactylus brachystoma are terrestrial and use the same microhabitats, such as termite mounds, fallen logs, rock crevices, and soil debris (Table 2).

Two points are against scorpions as models for mimicry. First, the absence of aposematic coloration in most species. Second, the apparent low abundance and richness of scorpions in the Cerrado. The lack of aposematism could be due to nocturnal habits of most species. However, the brilliant color of some species and the very characteristic morphology could be sufficient for predators to learn to identify and avoid them (Wüster et al. 2004). Batesian mimicry theory states that predators must find the model more often than the mimic. The low diversity of Cerrado scorpions seems to invalidate this for the present case. However, this parameter could be less important if the model is extremely 
Table 2 - Summary of scorpions and Coleodactylus brachystoma morphological, ethological, and behavioral characteristics.

\begin{tabular}{|c|c|c|}
\hline CHARACTERISTICS & Coleodactylus brachystoma & Buthid scorpions \\
\hline Tail Color & $\begin{array}{l}\text { Ventral surface pale-yellow or } \\
\text { orange }\end{array}$ & $\begin{array}{c}\text { Dorsal and ventral surfaces pale-yellow or } \\
\text { orange }\end{array}$ \\
\hline \multirow[b]{2}{*}{ Tail Size } & \multirow{2}{*}{$14.42-24.88 \mathrm{~mm}$} & $9.02-13.28$ in A. balzani \\
\hline & & $19.75-48.74$ in $R$. agamenon \\
\hline Tail Shape & $\begin{array}{l}\text { Elongated, curved over the body } \\
\text { when in defensive posture }\end{array}$ & $\begin{array}{l}\text { Elongated, curved over the body when in } \\
\text { defensive posture }\end{array}$ \\
\hline Palatability & Palatable & Sting toxic, body palatable \\
\hline Defenses & $\begin{array}{c}\text { Camouflage, crypsis, tail loss, skin } \\
\text { loss }\end{array}$ & Camouflage, crypsis, poisonous stings \\
\hline Geographic range & Cerrados of Central Brazil & $\begin{array}{l}\text { Cerrados and "cerrado-like" habitats of } \\
\text { South America (Lourenço 2002) }\end{array}$ \\
\hline Microhabitat use & $\begin{array}{l}\text { Dead logs, soil debris, soil holes, } \\
\text { rock crevices }\end{array}$ & $\begin{array}{c}\text { Dead logs, termite mounds, soil debris, soil } \\
\text { holes, rock crevices }\end{array}$ \\
\hline Daily activity & Diurnal and nocturnal & Mostly nocturnal \\
\hline Abundance & $\begin{array}{l}\text { Rare before habitat insularization, } \\
\text { very common now in Serra da } \\
\text { Mesa islands }\end{array}$ & Some species very common \\
\hline Behavior & $\begin{array}{l}\text { Slow moving, shy, aposematic } \\
\text { behavior when cornered }\end{array}$ & $\begin{array}{l}\text { Slow moving, shy, aposematic behavior } \\
\text { when cornered }\end{array}$ \\
\hline
\end{tabular}

dangerous for most predators. In this case, rare encounters between models and predators could be sufficient for predator's learning and avoidance of scorpions (Owen 1980, Pough 1988a, b). Scorpions are considered some of the most dangerous terrestrial invertebrates and, in Serra da Mesa, some species were very common, with a density of 40 individuals by hectare. Although the mean abundance of Coleodactylus brachystoma in Serra da Mesa islands and margins could be more than ten times higher than any scorpion species (Table 1 ), the total abundance of scorpions and $C$. brachystoma in Serra da Mesa where not different. So, an individual predator has similar chances to find a scorpion or a lizard when foraging.
Scorpions are well distributed and dangerous animals, allowing the evolution of abstract mimicry and innate avoidance (Rettenmeyer 1970, Brodie III and Brodie Jr. 1999). The size of $C$. brachystoma tail matches the metasoma lenght and color pattern of sympatric scorpion species, suggesting a complex mimetic system. However, more experimental studies are necessary before one could classify this system in the known mimicry models, and for determinate the occurrence of innate avoidance of scorpions by predators and the differential attack of predators upon "scorpion-like” lizards. These experiments involve the offering of scorpions to captive-born (naive) bird predators, and the use of plasticine models with raised and unraised tails in the field. 


\section{Acknowledgements}

To Adrian Garda, and Otávio Marques for critically reading preliminary versions of the manuscript and by some bibliography. To Wilson Lourenço for scorpion identifications. To Marcelo Cavallini for help with the figures. To Guarino Colli for help with literature and discussions. To Raymond Huey and two anonymous reviewers for relevant comments on the manuscript. To "Fundação O Boticário de Proteção à Natureza” for funding the project "Padrões de Riqueza e Abundância de Répteis e Anfíbios em Ilhas de Serra da Mesa, Minaçu, Goiás”.

\section{References}

Autumn, K. and B. Han. 1989. Mimicry of scorpions by juvenile lizards, Teratoscincus roborowskii (Gekkonidae). Chinese Herpetological Research 2: 60-64.

Ávila-Pires, T. C. S. 1995. Lizards of Brazilian Amazonia. (Reptilia: Squamata). Zoologische Verhandelingen 299: 1-706.

Bates, H. W. 1862. Contributions to an insect fauna of the Amazon Valley. Lepidoptera: Heliconidae. Transactions of the Linnean Society of London 23: 495566.

Brandão, R. A. 2002. Monitoramento das Populações de Lagartos (Sauria) no Aproveitamento Hidrelétrico de Serra da Mesa, Minaçu, Goiás. Unpublished PhD. Thesis. Universidade de Brasília, Brazil.

Brodie III, E. D. and E. D. Brodie Jr. 1999. Predator-prey arm races. Asymmetrical selection on predators and prey may be reduced when prey are dangerous. BioScience 49: 557-568.

Brownell, P. and G. Polis (eds.). 2001. Scorpion Biology and Research. New York and Oxford. Oxford University Press.

Colli, G. R., D. O. Mesquita, P. V. V. Rodrigues, and K. Kitayama. 2003. Ecology of the gecko Gymnodatylus geckoides amarali in a Neotropical savanna. Journal of Herpetology 37: 694-706.

Eiten, G. 1994. Vegetação do Cerrado. Pp. 17-74 in M. N. Pinto (ed.), Cerrado: Caracterização, Ocupação e
Perspectivas. Brasília. Editora da UnB.

Heatwole, H. 1967. Defensive behaviour of some Panamanian scorpions. Caribbean Journal of Sciences 7: 15-17.

Huey, R. B. and E. R. Pianka. 1977. Natural selection for juvenile lizards mimicking noxious beetles. Science 195: 201-203.

Lourenço, W. R. 2002. Scorpions of Brazil. Paris. Les Éditions de I’lf.

Lourenço, W. R. and V. R. D.von Eickstedt. 2003. Escorpiões de importância médica. Pp. 182-197 in J. L. C. Cardoso, F. O. S. França, F. H. Wen, C. M. S. Málaque, and V. Haddad Jr. (eds.), Animais Peçonhentos no Brasil: Biologia, Clínica e Terapêutica dos Acidentes. São Paulo. FAPESP and Sarvier.

Owen, D. 1980. Camouflage and Mimicry. Chicago. The University of Chicago Press.

Pianka, E. R. and L. J. Vitt. 2003. Lizards: Windows to the Evolution of Diversity. Berkeley. University of California Press.

Pough, F. H. 1988a. Mimicry and related phenomena. Pp. 153-234 in Gans, C. and R. B. Huey (eds.), Biology of Reptilia, Vol. 16, Ecology B. New York. Alan R. Liss.

Pough, F. H. 1988b. Mimicry of vertebrates: are the rules different? American Naturalist 131: S67-S102.

Rettenmeyer, C. W. 1970. Insect mimicry. Annual Review of Entomology 15: 43-74.

Ricklefs, R. E., D. Cochram, and E. R. Pianka. 1981. A morphological analysis of the structure of communities of lizards in desert habitat. Ecology 62:1474-1483.

Ribeiro, J. F. and B. M. T. Walter. 1998. Fitofisionomias do Bioma Cerrado. Pp. 87-166 in Sano, S. M. and S. P. Almeida (eds.), Cerrado: Ambiente e Flora. Brasília. EMBRAPA/CPAC.

Vitt, L. J. 1992. Lizard mimics millipede. National Geographic Research and Exploration 8: 76-95.

Vitt, L. J. and W. E. Cooper Jr. 1986. Tail loss, tail color, and predator escape in Eumeces (Lacertilia: Scincidae): age-specific differences in costs and benefits. Canadian Journal of Zoology 64: 583-592.

Wüster, W., C. S. E. Allum, B. Bjargardóttir, K. L. Bailey, K. J. Dawson, J. Guenioui, J. Lewis, J. McGurk, A. G. Moore, M. Niskanen, and C. P. Pollard. 2004. Do aposematism and Batesian mimicry require bright colours? A test, using European viper markings. Proceedings of the Royal Society of London Series B 271: 2495-2499. 